\title{
Presence of larger flatfish modifies habitat preference by Age-0 northern rock sole Lepidopsetta polyxystra
}

\author{
Clifford H. Ryer ${ }^{1, *}$, Allan W. Stoner ${ }^{1}$, Mara L. Spencer ${ }^{1}$, Alisa A. Abookire ${ }^{2}$ \\ ${ }^{1}$ Fisheries Behavioral Ecology Program, Alaska Fisheries Science Center, NOAA Fisheries, Hatfield Marine Science Center, \\ Newport, Oregon 97365, USA \\ ${ }^{2}$ Alaska Fisheries Science Center, NOAA Fisheries, Kodiak Laboratory, 301 Research Court, Kodiak, Alaska 99615, USA
}

\begin{abstract}
Essential fish habitat (EFH) is poorly defined for the early stages of most commercially important species. Age-0 flatfish making summer use of shallow coastal embayments around Kodiak Alaska distribute themselves according to a variety of bottom features. Both field and laboratory studies indicate that the numerically dominant species, northern rock sole Lepidopsetta polyxystra and Pacific halibut Hippoglossus stenolepis, demonstrate an affinity for seafloor with emergent structure: algae, shell, worm-tubes, etc. We conducted field manipulations, in which bivalve shell was scattered on the seafloor along 100 m transects, with the goal of examining movements of juvenile flatfish in response to these habitat alterations. In the first manipulation, contrary to expectations, Age-0 flatfish emigrated from the shell-enhanced seafloor, producing fish densities that were lower than on adjacent un-enhanced bottom. In comparison, larger flatfish, predominantly Age- $1^{+}$rock sole Lepidopsetta spp., increased in abundance on shell-enhanced bottom. Small flatfish may have moved to avoid larger flatfish. The manipulation was repeated at another site with similar physical features, but where large flatfish abundances are generally lower. This time, Age-0 flatfish densities were greater on the shell-enhanced bottom than on adjacent un-enhanced bottom. Again, large flatfish were more abundant on the shell bottom, but they were nearly an order of magnitude less abundant than in the first manipulation. In a subsequent laboratory experiment, Age-1 northern rock sole demonstrated stronger affinity for shell bottom than did Age-0 northern rock sole. In another experiment, Age-0 northern rock sole moved to avoid aggregations of larger conspecifics as well as other species of large flatfish. We conclude that these Age-0 flatfish, predominantly northern rock sole, perceive larger fish as predators and/or competitors, with habitat quality degraded by their presence. These results demonstrate that habitat quality for juvenile fish is influenced by biotic factors as well as by physical characteristics of habitat.
\end{abstract}

KEY WORDS: Habitat complexity $\cdot$ Habitat quality $\cdot$ Rock sole $\cdot$ Pacific halibut $\cdot$ Predator-prey interactions $\cdot$ Competitive interactions $\cdot$ Essential fish habitat $\cdot$ Indirect predation effects

\section{INTRODUCTION}

'A key element in moving toward sustainable fisheries is the identification, conservation, and restoration of fish habitat' (Schmitten 1999). This statement reflects a now widely accepted axiom: to effectively manage fish stocks, we must manage the habitats and ecosystem that support fish. Yet, for most commercially important species we have little understanding of what constitutes 'essential fish habitat' (EFH) or 'critical habitat'. Flatfish Pleuronectidae spp. represent an important fishery. As is the case for many finfish, juvenile flatfish often occupy a narrower range of habitats than do adults. In many cases, juvenile nursery 
grounds occur in shallow water-estuaries, nearshore waters and coastal embayments (Krygier \& Pearcy 1986, Norcross et al. 1999, Stoner et al. 2001, Gibson et al. 2002)-and, because of their areal restriction relative to adult habitat, may promote density dependent post-settlement processes that dampen inter-annual variation in recruitment to adult populations (Gibson 1994). Importantly, because of their depth and proximity to human population centers, these habitats are arguably subject to greater natural and anthropogenic disturbances, including habitat fragmentation (Hovel \& Lipcius 2001, Laurel et al. 2003) and degradation (Collie et al. 2005), than are adult habitat.

Juvenile flatfish habitat has typically been characterized by physical factors, including depth, temperature, salinity and, perhaps most importantly given that these fish demonstrate such an intimate association with the seafloor, sediment characteristics such as grain size and organic content (Rogers 1992, Swartzman et al. 1992, Jager et al. 1993, Abookire \& Norcross 1998, Norcross et al. 1999, McConnaughey \& Smith 2000, Amezcua \& Nash 2001, Stoner \& Abookire 2002, Able et al. 2005). Sediment preferences often change with ontogeny, reflecting burial capabilities (Gibson \& Robb 1992, Stoner \& Ottmar 2003). However, within broad areas of suitable sediment characteristics, some species of juvenile flatfish, as well as other fishes, aggregate on bottom with secondary emergent features, such as shells, cobble, burrows, feeding pits and sand waves (Auster et al. 1996, Thrush et al. 2002, Abookire et al. 2007), which presumably enhance habitat quality (Gibson 1994). For example, juvenile winter flounder Pseudopleuronectes americanus settle onto muddy sediments, but by the time they reach $55 \mathrm{~mm}$ often associate with drift algae Ulva lactuna and Gracilaria sp. and eelgrass Zostera marina (Stoner at al. 2001, Goldberg et al. 2002), as well as with woody debris and shells (Howell et al. 1999). Northern rock sole Lepidopsetta polyxystra and Pacific halibut Hippoglossus stenolepis also aggregate in and around bottom featuring drift algae, but distribute themselves most strongly relative to worm tubes (Amphaeretidae), aggregating around low to moderate densities of worm tubes, while avoiding continuous worm-tube 'turf' (Stoner et al. 2007).

Structurally complex habitats often provide refuge from predation. In laboratory studies, winter flounder are less vulnerable to predation in vegetated habitats (Manderson et al. 2000). Similarly, rock sole and Pacific halibut are less vulnerable to predation in sponge habitats, as sponges interfere with predator search and facilitate prey escape (Ryer et al. 2004). Predation risk, which can differ from one area of the seafloor to the next, may also have indirect influences on prey behavior (Parsons \& Eggleston 2006). Juvenile northern rock sole, Pacific halibut and English sole Parophrys vetulus decrease activity, assume a lower body profile and are more likely to bury when they perceive predators nearby: behavior incompatible with foraging (Lemke \& Ryer 2006a). If predation risk is persistent, fish may relocate to areas of lower perceived risk (Werner \& Hall 1988) or, if unable to emigrate, could be expected to experience slower growth (Killen \& Brown 2006, C. H. Ryer \& T. P. Hurst unpubl.). As such, predation risk is likely to have both a direct and indirect influence upon habitat quality for juvenile flatfish.

In this study we describe the results of a series of field and laboratory experiments designed to examine the preference of Age-10 northern rock sole (hereafter rock sole) for structurally complex benthic habitats in their nursery embayments on the eastern end of Kodiak Island, Alaska. Initially, the experiments were designed to test the hypothesis that juvenile flatfish would immigrate to areas of bottom where habitat complexity was enhanced through the addition of bivalve shell, resulting in higher fish densities compared with adjacent un-enhanced control bottom. Prior field and laboratory data indicated that juvenile flatfish densities were positively correlated with the abundance of emergent structure (including shell), and habitat choice experiments indicated that both Age-10 rock sole and Age-0 Pacific halibut (hereafter halibut) preferred habitats containing shell (Stoner \& Titgen 2003). However, results of our initial field experimentation suggested that perceived predation risk and/or competitive interactions associated with larger flatfish, which differed between our treatments in a counterintuitive manner, influenced the habitat preference of juvenile rock sole. Thus, subsequent experiments were designed to address this development, resulting in an integrated field and laboratory study of the influence of larger flatfish upon habitat preference by Age-0 rock sole.

\section{MATERIALS AND METHODS}

Field habitat manipulations. Our first manipulation was conducted during July 2003 at Pillar Creek Cove (57 $49^{\prime} \mathrm{N}, 152^{\circ} 25^{\prime} \mathrm{W}$, Fig. 1). During summer months, when rock sole and halibut utilize this nursery area, freshwater outflow from the creek is minimal, with salinities in the range of 30.7 to $31.3 \%$ and water temperatures ranging from 5.0 to $11.1^{\circ} \mathrm{C}$. At the beginning of the experiment, the Age-0 flatfish community was characterized from a sample of 417 fish, captured using a $2 \mathrm{~m}$ beam trawl ( $3 \mathrm{~mm}$ mesh) from the area where experimental treatments were to be set out. The next day, Pacific oyster Crassostrea gigas shell was scat- 


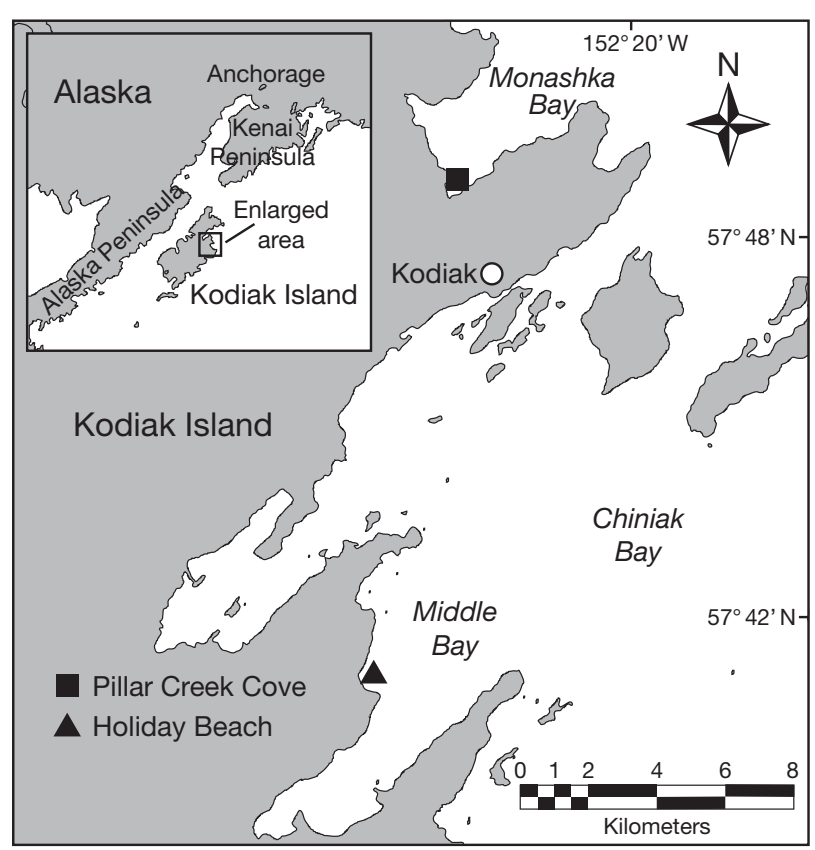

Fig. 1. Study sites Pillar Creek Cove and Holiday Beach on northeast Kodiak Island. Inset: location relative to Alaskan mainland and Alaskan Peninsula

tered on the bottom along 5 parallel 100 m transects, running the long axis of the cove in depths ranging from 6.6 m MLLW (mean lower low water) inshore to $13.8 \mathrm{~m}$ MLLW offshore. Our intention was to create swaths of shell approximately 4 to $6 \mathrm{~m}$ wide in which shell density would be approximately 5 valves $\mathrm{m}^{-2}$. Because naturally occurring shell is sparse in the cove, each shell treatment was paired with a control treatment-a transect characterized by lower structural complexity, which ran parallel to the shell transect at a distance of 12 to $24 \mathrm{~m}$ (average $=17.3 \mathrm{~m}$ ). Both control and shell treatments were surveyed, in random order, with a towed video camera sled (Spencer et al. 2005). Briefly, the sled was $67 \mathrm{~cm}$ wide, $114 \mathrm{~cm}$ long and carried a video camera that fed imagery to the surface where it was recorded on digital tape. Concurrently, GPS coordinates and depth were streamed into a computer at $5 \mathrm{~s}$ intervals. The camera sled was lowered to the bottom on the inshore end of each treatment and towed the length of the treatment at a speed of approximately $60 \mathrm{~cm} \mathrm{~s}^{-1}$. The video camera provided an oblique view of the approaching seafloor that was $67 \mathrm{~cm}$ wide at the base and $250 \mathrm{~cm}$ at the top when viewed on the video monitor. The maximum forward view was $320 \mathrm{~cm}$. The parallel runners of the sled appeared in the camera view, along with a tickler chain attached to the runners at the most forward point of contact with the sediment. In this way, flatfish were observable and quantifiable as they flushed from the seafloor in response to disturbance by the chain. Otherwise, the sled and tickler chain had little impact upon the bottom, other than rolling over some of the shells. Surveys were repeated 2, 4, 8, and 42 d later. After the last survey, the Age-0 flatfish community was again characterized from a sample of 261 fish taken from the experimental area with the $2 \mathrm{~m}$ beam trawl.

Video analysis for the shell treatments was confined to sections of video where the camera sled was in the shell swath. Sections were omitted from analysis when the camera sled veered away from the shell swath or when there was a gap in the shells spanning a $5 \mathrm{~s}$ interval. For the control treatments, video analysis was confined to sections where the camera sled was between the established inshore and offshore end points. For this we used the GPS coordinates obtained during videotaping and corrected for the distance of the camera sled behind the boat. For both control and shell treatments, video sections were omitted from analysis if the tickler chain was not in contact with the bottom. The total length of the analyzed section of video for each treatment was calculated as the distance between the starting and ending latitude and longitude points minus the lengths of omitted sections. Age-0 and larger flatfishes were distinguishable because of the distinct size separation between them. Age-0 flatfishes (<60 mm), Age-1 and greater flatfishes (>80 mm), and shells (including oyster shells and other empty bivalve shells $>5 \mathrm{~cm}$ diameters) were enumerated. Only Age-0 flatfishes and shells observed between the 2 sides of the sled were counted. These counts were adjusted to counts per $100 \mathrm{~m}^{2}$ based on the length of the analyzed section of video and the width of the camera sled $(67 \mathrm{~cm})$. All larger flatfishes within camera view were counted. These counts were adjusted to counts per $100 \mathrm{~m}$ based on the length of the analyzed section. If the sled was tracking along the edge of a shell transect, there were instances where larger flatfishes that were up to $150 \mathrm{~cm}$ outside of the transect were counted. Density data for Age-0 flatfish, larger flatfish, and shell conformed to parametric assumptions, i.e. normality and homogeneity of variance. Data were analyzed using nested-factorial ANOVAs, where treatment (shell vs. control) was nested within transect pairs (Hicks 1982).

Our second habitat manipulation was conducted at Holiday Beach $\left(57^{\circ} 41^{\prime} \mathrm{N}, 152^{\circ} 27^{\prime} \mathrm{W}\right)$, located in Middle Bay, during August 2004. This site was chosen because video-sled surveys in 2002 and 2003 indicated lower abundances of larger flatfish, mostly rock sole Lepidopsetta spp., than at the Pillar Creek Cove site. Salinities range from 30.9 to $31.3 \%$ and water temperatures from 6.1 to $10.6^{\circ} \mathrm{C}$ during summer. Again, oyster shell was scattered on the bottom along 5 parallel $100 \mathrm{~m}$ transects in depths ranging from 9.6 m MLLW inshore 
to $12.5 \mathrm{~m}$ MLLW offshore. Both control and shell treatments were surveyed with the towed video camera sled on Day 0 and Day 20. Treatments were also surveyed on Days 2 and 23 using a $2 \mathrm{~m}$ beam trawl fitted with a camera, allowing for minor course changes to assure that the trawl stayed on track. The cameraequipped beam trawl was lowered to the bottom on the inshore end of each treatment and towed at $70 \mathrm{~cm} \mathrm{~s}^{-1}$ until the trawl reached the offshore end, at which point the vessel speed was increased to lift the net off the bottom while the net was retrieved. The trawl removed some shell from the bottom, but we judged this impact to be minimal because the largest 'catch' of shell in a single haul was 82 valves: less than $4 \%$ of what was added to the bottom for each treatment. Flatfish were enumerated and identified to species level.

Video footage from the camera sled was analyzed as previously described. For the trawl, flatfish catch was adjusted to counts per $100 \mathrm{~m}^{2}$ based on the distance trawled and the effective fishing width of the trawl $(1.8 \mathrm{~m})$. For all shell treatments, the trawl remained within the swath of shell. Densities of fish acquired from both the camera sled and the trawl were analyzed in a single nested-factorial ANOVA, where treatment was nested within transect pairs and gear (sled vs. trawl) was considered a variable along with day (Hicks 1982). Data were considered to have either been acquired at the 'beginning' (sled: Day 0; trawl: Day 2) or at the 'end' (sled: Day 20; trawl: Day 23) of the study.

Laboratory experiments. Age-0 Pacific halibut and rock sole were collected with a beam trawl ( $2 \mathrm{~m}$ wide, $3 \mathrm{~mm}$ mesh) and, after holding at the Kodiak Fisheries Research Center for 2 to $3 \mathrm{~d}$, were air transported to the National Marine Fisheries Service (NMFS) laboratory at the Hatfield Marine Science Center in Newport, Oregon. Age-1 and Age-2 rock sole and halibut were similarly collected as Age-0 juveniles and grown out in the laboratory. Adult starry flounder were received on loan from the Oregon Coast Aquarium.

Age-0 rock sole and Pacific halibut were maintained in $2 \mathrm{~m}$ diameter (3000 l) tanks. At $2 \mathrm{yr}$ of age, (Pacific halibut) fish were transferred to $2.9 \mathrm{~m}$ diameter (6400 l) tanks. All tanks had a thin layer of sand on the bottom and flow-through $9^{\circ} \mathrm{C}\left( \pm 1^{\circ}\right)$ seawater. Age-0 Pacific halibut and rock sole were fed to satiation thrice weekly on a gel food diet comprised of squid, herring, krill, amino acid supplements and vitamins. Age-1 and -2 halibut were fed thrice weekly on a diet of gel food as well as whole squid Loligo spp.. Four weeks prior to the initiation of predation trials, the diet of Age-2 halibut predators was expanded to include live Age-0 flatfish in order to reacquaint them with live prey.

An experiment was conducted to determine whether Age-0 rock sole and halibut demonstrate preference for habitat characterized by structural complexity in the form of oyster shell. Habitat preference trials were conducted in $2.9 \mathrm{~m}$ diameter arenas, provided with flow-through $9^{\circ} \mathrm{C}\left( \pm 1^{\circ}\right)$ seawater to a depth of $1 \mathrm{~m}$. Arena bottoms were covered with a $3 \mathrm{~cm}$ deep layer of a $2: 1$ ratio mixture of coarse $(1.0 \mathrm{~mm})$ and medium $(0.5 \mathrm{~mm})$ sand, allowing flatfish to bury completely. The sand was raked smooth before each trial, and then one side of each arena was randomly selected to receive 15 oyster Crassostrea gigas valves (10 to $18 \mathrm{~cm}$ ) achieving a density of 4.5 valves $\mathrm{m}^{-2}$ on that side of the arena. Fish were accustomed to a 12:12 h light:dark photoperiod, with darkness from 1900 to $0700 \mathrm{~h}_{\text {; this }}$ was continued during preference trials. Light levels in the room containing the arenas were approximately $5 \mu \mathrm{mol}$ photons $\mathrm{m}^{-2} \mathrm{~s}^{-1}$ during the day and $<1 \times$ $10^{-8} \mu \mathrm{mol}$ photons $\mathrm{m}^{-2} \mathrm{~s}^{-1}$ at night. Both Age- 0 rock sole and halibut were starved for $48 \mathrm{~h}$ prior to being introduced to the arenas. Introduction occurred $4 \mathrm{~h}$ prior to the initiation of trials, when fish were placed into a $62 \mathrm{~cm}$ diameter plexiglass ring that was positioned in the center of each arena such that it encompassed equal portions of both the sand and shell habitats. Owing to differing numbers of each species/age available, Age-0 rock sole trials were conducted with 20 fish, Age-1 rock sole trials with 15 fish and Age-0 halibut trials with 17 fish. Trials commenced at 13:00 h when the ring was raised and removed from the tank. Trials were terminated at 13:00 h the next day, when a divider was lowered from the ceiling to separate the 2 habitat types and prevent the fish from changing sides. The water level was then lowered to approximately $10 \mathrm{~cm}$, facilitating removal of the shells and then the fish. To recover fish, each side of the arena was methodically raked, dip-netting the fish as they moved. All fish were recovered in each trial. Fish were subsequently measured for total length. Age-0 rock sole length ranged from 44 to $79 \mathrm{~mm}$ (mean $=55$, $\mathrm{SD}=7$ ), Age-1 rock sole from 122 to 190 (mean = 149, $\mathrm{SD}=14$ ) and Age-0 halibut from 52 to 115 (mean = 85, $\mathrm{SD}=11$ ). No fish were used more than once. Mean lengths of fish recovered from each habitat were homoscedastic and normally distributed, and were therefore compared using a $t$-test (Sokal \& Rohlf 1969). Data on habitat occupancy were analyzed using G-tests (Sokal \& Rohlf 1969), first testing for heterogeneity and then for deviation from a 50:50 ratio of frequency distribution between habitats.

A second experiment was conducted to determine whether Age-0 rock sole would redistribute themselves to avoid larger flatfishes. Again, trials were conducted in $2.9 \mathrm{~m}$ arenas at $9^{\circ} \mathrm{C}\left( \pm 1^{\circ}\right)$ with the arena bottoms covered by $3 \mathrm{~cm}$ of sand. Plastic mesh fencing (35 mm horizontal $\times 25 \mathrm{~mm}$ vertical openings) divided each arena in half. This mesh fence did not significantly impede the movements of Age-0 rock sole: pre- 
liminary trials demonstrated that when 20 fish were placed on one side of the barrier, equal numbers were found on either side of the barrier the following day (paired $t_{[5]}=1.28, \mathrm{p}=0.258$ ). In large fish avoidance trials, 20 Age- 0 rock sole were introduced to arenas at 13:00 $\mathrm{h}$ with the lights off, 10 fish to either side of the fence. One randomly selected side of each arena also contained larger flatfish: either 5 Age-1 rock sole, 3 Age-1 halibut, or 2 adult starry flounder Platichthys stellatus. In trials that utilized Age-1 rock sole and Age-1 halibut, these larger fish were introduced to arenas $48 \mathrm{~h}$ prior to initiation of trials and were not fed in the arenas. In the case of starry flounder, only 2 pairs of fish were available. Each pair remained in their respective arenas, on the same side, for the duration of the trials and went unfed. Trials were initiated by turning the lights back on, 30 min after Age-0 rock sole had been introduced to the arenas. Then, $24 \mathrm{~h}$ later, dividers were lowered from the ceiling to segregate the 2 sides and fish were removed, as per protocols presented above, and measured.

Six trials were conducted for each of the larger fish treatments and no Age-0 rock sole were reused in successive trials. No Age- 0 rock sole went missing (i.e. were eaten) during the trials with larger Age-1 rock sole or starry flounder. Three Age-0 rock sole went missing in trials with larger halibut (1 in one trial, 2 in another), were presumably eaten, and, to be conservative, were added to the recovery count for the large fish side of the arena. Age-0 rock sole total lengths ranged from 43 to $70 \mathrm{~mm}$ (mean $=55, \mathrm{SD}=6$ ) in larger rock sole trials, 43 to $74 \mathrm{~mm}$ (mean $=56, \mathrm{SD}=6$ ) in larger halibut trials, and 45 to $75 \mathrm{~mm}$ (mean $=59$, $\mathrm{SD}=6$ ) in starry flounder trials. Although Age-0 rock sole were, on average, larger in starry flounder trials than in either larger rock sole or halibut trials (Tukey's Honestly Significant Difference [HSD], p < $\left.0.05, F_{[2,15]}=11.13, \mathrm{p}=0.001\right)$, we consider this minor difference to be of little significance in the context of this study. There were no differences in fish sizes recovered from 'large fish' vs. 'no large fish' sides of the arena $\left(F_{[1,15]}=0.04, \mathrm{p}=0.849\right)$ or any higher level interactions. Large fish total lengths ranged from 155 to $188 \mathrm{~mm}$ (mean $=167, \mathrm{SD}=9)$ for Age-1 rock sole, 255 to $295 \mathrm{~mm}$ (mean $=277, \mathrm{SD}=13$ ) for halibut, and 395 to $470 \mathrm{~mm}$ (mean $=433, \mathrm{SD}=35$ ) for starry flounder. Data on the frequency of Age-0 rock sole recovered on either side of arenas were analyzed using G-tests (Sokal \& Rohlf 1969), first for heterogeneity, then for differences among large fish treatments (different species), and finally for deviation from a 50:50 ratio of frequency distribution between sides.

Lastly, an experiment was conducted to determine whether occupancy of benthic habitats containing structural complexity in the form of scattered oyster shell lessens juvenile rock sole and halibut vulnerability to predation. Trials were again conducted in $2.9 \mathrm{~m}$ arenas at $9^{\circ} \mathrm{C}\left( \pm 1^{\circ}\right)$. In these trials, the entire bottom of each arena was covered either with $3 \mathrm{~cm}$ of sand, or sand plus oyster shell (150 valves, 22.7 valves $\mathrm{m}^{-2}, 16 \%$ areal coverage). This density of shell was approximately 5 times greater than in the field preference experiments, and was chosen to maximize its potential as a refuge from predation and to make the result directly comparable with an earlier study that examined refuge value of $16 \%$ areal coverage of sponge to juvenile flatfish (Ryer et al. 2004). The sand was raked smooth $48 \mathrm{~h}$ prior to the trails and, for shell trials, the 150 shells were then dispersed in an approximately uniform pattern. As in prior experiments, shell coverage extended to the walls of the arena, thereby preventing either predator or prey from avoiding the shells by swimming around the arena's perimeter. Next, 2 Age-2 halibut predators, which had been starved for $48 \mathrm{~h}$, were released into each arena. Then, $48 \mathrm{~h}$ later and $30 \mathrm{~min}$ prior to initiation of trials, the lighting in the room containing the arenas was turned off and 20 prey (either Age-0 rock sole or halibut) that had been starved for $48 \mathrm{~h}$ and measured were released into the arena. These starvation periods for predators and prey were consistent with those used in the prior habitat preference studies (present study and Ryer et al. 2004). At 11:00 h, 30 min later, the lights were turned back on in order to initiate the trials. Trials were terminated at $15: 00 \mathrm{~h}$ by lowering the water level to $\sim 10 \mathrm{~cm}$ and initiating shell and prey recovery/ measurement, as previously described.

Although Age-0 rock sole and halibut were not utilized again in subsequent trials, the 12 halibut predators were reallocated (shuffled) among the 6 arenas. Thus, while reused, we assumed that this randomization precluded any tank/predator effects owing to the repeated use of these predators. To minimize predator stress, they were not measured for total length until the conclusion of the $4 \mathrm{wk}$ required to complete the experiment. Six replicate trials were conducted for Age-0 rock sole and halibut in both sand and shell habitats. Total fish length ranged 43 to $80 \mathrm{~mm}$ for Age-0 rock sole (mean $=55$ ) and 33 to $90 \mathrm{~mm}$ for halibut (mean = $65)$, such that mean fish size for rock sole trials was on average $10 \mathrm{~mm}$ smaller than that for halibut trials $\left(F_{[1,20]}=102.40, \mathrm{p}<0.001\right)$, reflecting the inherently slower growth rate characteristic of rock sole compared with that of halibut (Ryer et al. 2004). Mean fish lengths for trials did not differ between habitats $\left(F_{[1,20]}=0.21, \mathrm{p}=0.652\right)$. Fish that survived in the sand habitat were on average $1 \mathrm{~mm}$ longer than fish going into trials, whereas fish surviving in the shell-sand habitat were $3 \mathrm{~mm}$ shorter (before-after $\times$ habitat interaction; $\left.F_{[1,19]}=4.85, \mathrm{p}=0.040\right)$. Although significant, 
we considered this pattern and degree of size-selectivity by the Age-2 halibut predators in these respective habitats to be trivial and assumed that it had no confounding effects on other factors examined in this study. Total lengths for the 12 Age-2 halibut predators ranged from 340 to $385 \mathrm{~mm}$ ( mean $=360, \mathrm{SD}=15)$. After confirming that data met assumptions of homoscedasticity and normality, the number of Age-0 flatfish consumed by the Age-2 halibut predators was analyzed by ANOVA in order to examine the effects of prey species and habitat.

\section{RESULTS}

\section{Field habitat manipulations}

At the initiation of the Pillar Creek Cove habitat manipulation, the Age-0 flatfish community, censused with $2 \mathrm{~m}$ beam-trawl, was dominated by rock sole $(96 \%)$. Halibut were relatively less common $(2 \%)$, and other species including Pacific sanddab Citharichthys sordidus, butter sole Isopsetta isolepis and arrowtooth flounder Atheresthes stomias constituted only $2 \%$ combined. Our manipulation resulted in 5 parallel 100 m swaths of shell $\sim 5 \mathrm{~m}$ wide, each paired with an adjacent control: a comparable tract of unenhanced seafloor. Initially, valve density (both natural and introduced) averaged 4.5 valves $\mathrm{m}^{-2}(\mathrm{SD}=0.9)$ in the shell treatments, and 0.1 valves $\mathrm{m}^{-2}(\mathrm{SD}=0.1)$ in control treatments. After $40 \mathrm{~d}$, valve density had decreased to $2.9(\mathrm{SD}=0.9)$ and 0.1 valves $\mathrm{m}^{-2}(\mathrm{SD}=0.1)$ in shell and control treatments, respectively, and much of this had partially settled into the sediment.

Age-0 flatfish density, as ascertained with the video sled, differed significantly between shell and control treatments $\left(F_{[1,20]}=14.42, \mathrm{p}=0.001\right)$. However, contrary to expectations, Age-0 flatfish densities were greater in control than in shell treatments (Fig. 2a). There was no effect of day on Age-0 flatfish density $\left(F_{[4,20]}=1.87\right.$, $\mathrm{p}=0.155)$, and although visual inspection of Fig. 2a suggests a lack of difference between control and shell treatments by the end of the experiment (Day 40), there was no statistically significant interaction between treatment and date $\left(F_{[4,20]}=1.45, \mathrm{p}=0.256\right)$. At the end of the experiment, rock sole $(95 \%)$ were still numerically dominant, with halibut less common $(5 \%)$ and other species absent from beam-trawl tows.

Larger $\left(\right.$ Age $\left.-1^{+}\right)$flatfish demonstrated a pattern opposite of that observed for Age-0 flatfish (Fig. 2b). Large flatfish appeared to be more abundant in the shell, as opposed to control treatments, except at the very beginning and at the conclusion of the experiment. As a consequence, there was a significant treatment $\times$ day interaction $\left(F_{[4,20]}=3.17, \mathrm{p}=0.036\right)$, but the
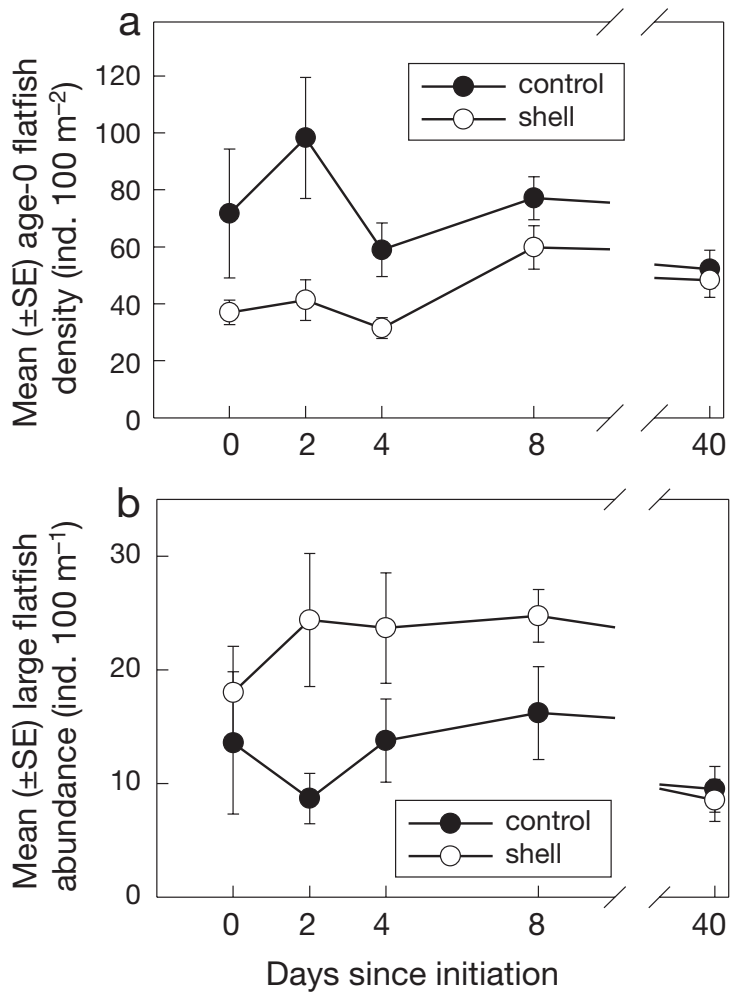

Fig. 2. Results of habitat manipulation at Pillar Creek Cove. (a) Mean density $( \pm$ SE) of Age-0 flatfish, and (b) mean abundance $( \pm \mathrm{SE})$ of larger Age- $1^{+}$flatfish on shell-enhanced (shell) and non-enhanced (control) transects. Densities for Age-0 flatfish were based on counts of fish observed between the runners of the video sled for the length of transects and were standardized to ind. $100 \mathrm{~m}^{-2}$. Abundances for larger Age $-1^{+}$represent the no. of fish observed within the video sled's field of view over the length of transects and are standardized to ind. $100 \mathrm{~m}^{-1}$

only day on which the shell differed significantly from the control was Day 2 (Tukey's pairwise comparison, $\mathrm{p}<0.05$ ). The $2 \mathrm{~m}$ beam trawl was inefficient at capturing large flatfish for identification; however, from video it was apparent that most of these large flatfish were either northern rock sole or southern rock sole Lepidopsetta bilineata.

The following year, at the initiation of our Holiday Beach habitat manipulation, rock sole again dominated the Age- 0 flatfish community $(82 \%)$; however, halibut were proportionately more common $(17 \%)$ than at the Pillar Creek Cove site (ascertained by $2 \mathrm{~m}$ beam trawl on Day 2). The remaining $1 \%$ of Age-0 flatfish were English sole Parophrys vetulus and yellowfin sole Limanda aspera. Mean shell density, as ascertained by video sled on Day 0, was 4.2 valves $\mathrm{m}^{-2}$ $(\mathrm{SD}=0.6)$ in shell treatments and 0.1 valves $\mathrm{m}^{-2}$ $(S D=0.1)$ in controls. After $20 \mathrm{~d}$, valve density had decreased to $2.5(\mathrm{SD}=0.5)$ and 0.1 valves $\mathrm{m}^{-2}(\mathrm{SD}=0.1)$ 
in shell and control treatments, respectively. Again, much of this had partially settled into the sediment.

For Age-0 flatfish, we combined video sled and beam trawl data in a single analysis, considering sampling to have either occurred at the beginning (sled: Day 0; trawl: Day 2) or at the end (sled: Day 20; trawl: Day 23) of the study (Fig. 3a). Contrary to results at Pillar Creek Cove the previous year, Age-0 flatfish were now more abundant in shell than in control treatments $\left(F_{[1,16]}=6.39, \mathrm{p}=0.022\right)$. There was a trend for density estimates acquired using the video sled to be somewhat higher than those from the beam trawl; however, this was not statistically significant $\left(F_{[1,16]}=\right.$ $3.72, \mathrm{p}=0.072$ ). There was no effect of date (beginning vs. end) on Age-0 flatfish density $\left(F_{[1,20]}=0.04\right.$,
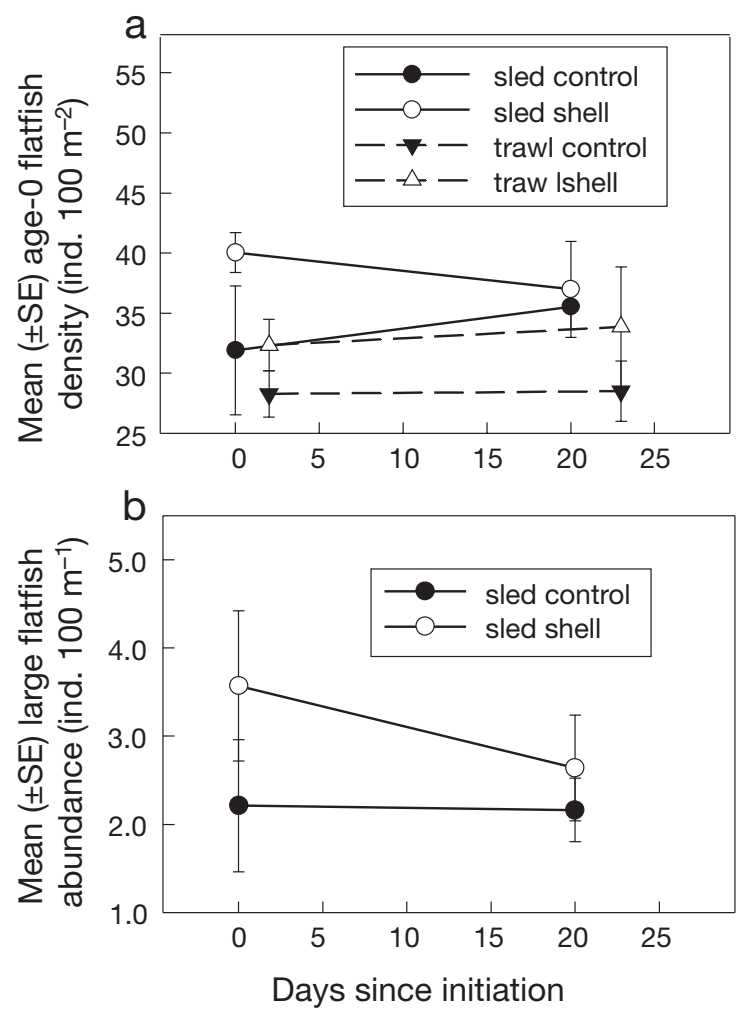

Fig. 3. Results of habitat manipulation at Holiday Beach. (a) Mean density ( \pm SE) of Age-0 flatfish, and (b) mean abundance $( \pm \mathrm{SE})$ of larger Age- $1^{+}$flatfish on shell-enhanced (shell) and non-enhanced (control) transects. Densities for Age-0 flatfish from the sled tows (sled) were based on counts of fish observed between the runners of the video sled over the length of transects and were standardized to ind. $100 \mathrm{~m}^{-2}$. Densities for Age-0 flatfish from trawl tows were based on catch over the known area swept by the trawl, similarly standardized to ind. $100 \mathrm{~m}^{-2}$. Abundances for larger Age $-1^{+}$from sled tows represent the no. of fish observed within the video sled's field of view over the length of transects and were standardized to ind. $100 \mathrm{~m}^{-1}$. Densities of large flatfish were not estimated from trawls because the $2 \mathrm{~m}$ beam trawl used in this study was inefficient at capturing these larger fish $\mathrm{p}=0.837$ ), or any significant higher level interactions between these variables ( $p>0.300$ for each). Using data from the beam trawl series alone, we examined species-specific responses to our habitat manipulation. Although demonstrating trends similar to the effect observed in the combined Age-0 flatfish analysis, there was no significant effect of shell presence or absence on the density of either Age-0 rock sole $\left(F_{[1,8]}=3.91, \mathrm{p}=0.084\right)$ or halibut $\left(F_{[1,8]}=0.35, \mathrm{p}=\right.$ $0.569)$. The only other noteworthy result of this analysis was a significant decrease in overall halibut densities from the beginning to the end of the experiment $\left(F_{[1,8]}=14.09, \mathrm{p}=0.006\right)$. While rock sole continued to dominate the Age-0 flatfish community (90\%), halibut proportional abundance had decreased from $17 \%$ at experiment initiation to $9 \%$ at the conclusion, with yellowfin sole and English sole together accounting for the remaining $1 \%$.

As seen during the previous year at Pillar Creek Cove, there was a tendency for large fish to be more abundant in shell as opposed to control treatments (Fig. 3b); however, this difference did not achieve statistical significance at Holiday Beach $\left(F_{[1,8]}=4.69, \mathrm{p}=\right.$ 0.062). There was no change in large flatfish abundance between the beginning and end of the experiment $\left(F_{[1,8]}=0.35, \mathrm{p}=0.573\right)$, or any interaction between treatment and date $\left(F_{[1,8]}=1.05, \mathrm{p}=0.335\right)$. However, as expected, the overall abundance of large flatfish at Holiday Beach was significantly lower than at Pillar Creek Cove in the previous year (Figs. 2b \& $3 \mathrm{~b})$, as revealed by comparison of fish abundances from the beginning (Day 0$)$ of each experiment $\left(F_{[1,8]}=\right.$ 12.01, $p=0.009)$. As in the prior field experiment, examination of video footage indicated that large flatfish were predominantly northern or southern rock sole.

\section{Laboratory habitat preference experiment}

Preference for bare sand vs. shell-sand differed somewhat among Age-0 rock sole, Age-1 rock sole, and Age-0 halibut (Fig. 4). Among the 6 trials conducted with Age- 0 rock sole, more fish were recovered from the sand side of the arena in 3 trials, more from the shell-sand side in 2 trials, with equal recovery from either side in a single trial, demonstrating significant variability in outcome ( $G=14.16$, $\mathrm{df}=5, \mathrm{p}=0.015)$. Results were more consistent for Age-1 rock sole, with more fish recovered from the shell-sand side of the arena in all 6 trials $(G=6.98, \mathrm{df}=5, \mathrm{p}=0.236$ ). Age- 0 halibut demonstrated similarly consistent results: in 8 out of 9 trials more fish were recovered from the shellsand side of the arena, with only 1 trial in which more were found on the sand side $(G=13.98$, $\mathrm{df}=8, \mathrm{p}=$ $0.082)$. When data were pooled across replicates, sig- 


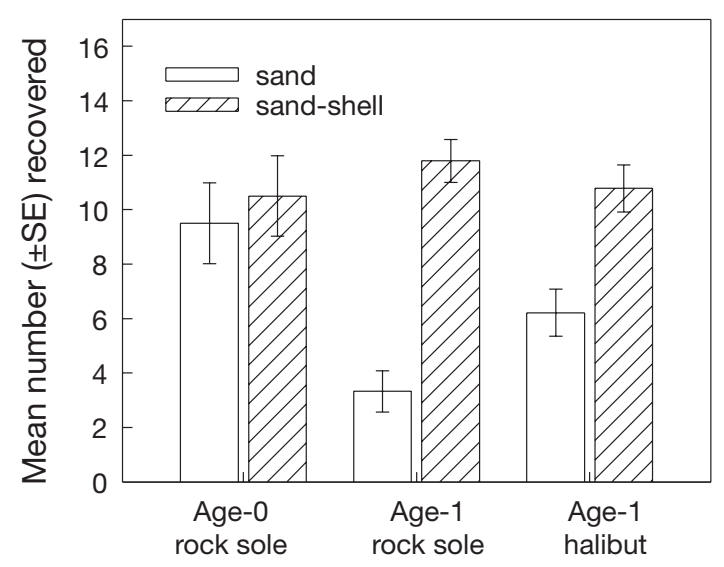

Fig. 4. Habitat preference. Mean number $( \pm \mathrm{SE})$ of Age- 0 rock sole Lepidopsetta polyxystra, Age-1 rock sole, or Age-0 Pacific halibut Hippoglossus stenolepis recovered from sand vs. sandshell sides of $3 \mathrm{~m}$ arenas, $24 \mathrm{~h}$ after their release

nificant differences in habitat preference were apparent between species $(G=15.02, \mathrm{df}=2, \mathrm{p}=0.001)$, with Age-1 rock sole demonstrating the strongest preference for the sand-shell habitat and Age-0 rock sole exhibiting the least. Subsequent testing against a null hypothesis (50:50 ratio of distribution between habitats) indicated no habitat preference by Age-0 rock sole $(G=1.392, \mathrm{df}=1, \mathrm{p}=0.238)$ but significant preference for the shell-sand habitat by both Age-1 rock sole $(G=31.09, \mathrm{df}=1, \mathrm{p}<0.001)$ and Age-0 halibut $(G=$ 12.57, $\mathrm{df}=1, \mathrm{p}<0.001)$. The mean size of fish recovered from sand vs. sand-shell did not differ for either Age- 0 rock sole $\left(t_{[10]}=-1.51, \mathrm{p}=0.161\right)$, Age- 1 rock sole $\left(t_{[10]}=0.31, \mathrm{p}=0.763\right)$ or Age- 0 halibut $\left(t_{[16]}=\right.$ $-1.53, \mathrm{p}=0.145$ ).

\section{Laboratory large fish avoidance experiment}

When given the choice of occupying sides of an arena either with or without larger flatfish, age-0 rock sole modified their distribution to avoid these larger fish (Fig. 5). In 4 out of 6 trials in which Age-1 rock sole were used as larger fish, more Age-0 rock sole were recovered from the 'large fish absent' side of the arena, constituting significant variability in outcome between replicates $(G=15.58, \mathrm{df}=5, \mathrm{p}=0.008)$. Results were more consistent when Age-1 halibut were utilized as the larger fish: more Age-0 rock sole were recovered from the side without large fish in all 6 trials $(G=4.27$, $\mathrm{df}=5, \mathrm{p}=0.511$ ). Similarly consistent results were obtained when adult starry flounder were the large fish, with more age- 0 rock sole again recovered from the side without large fish in all 6 trials $(G=2.41, \mathrm{df}=5, \mathrm{p}$ $=0.791)$. When data were pooled across replicates, dis-

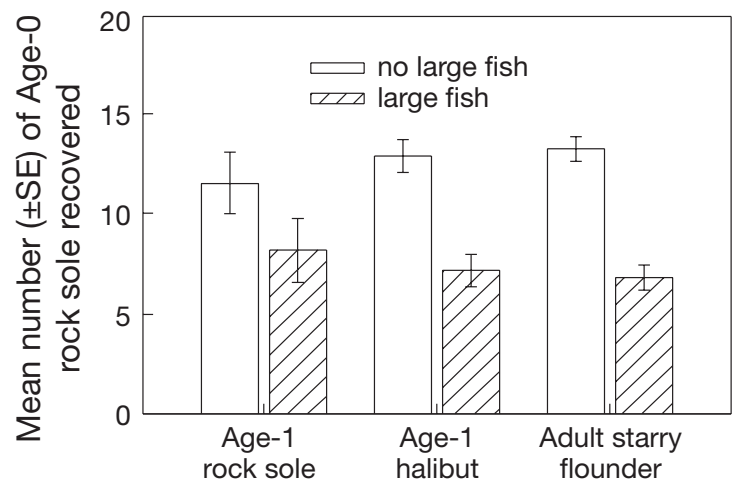

Fig. 5. Response to threat. Mean number $( \pm \mathrm{SE})$ of Age- 0 rock sole Lepidopsetta polyxystra recovered from either the 'large fish' side of the $3 \mathrm{~m}$ arena or the opposite side (containing no large fish) $24 \mathrm{~h}$ after release. In each of 3 sets of trials, large fish were Age-1 rock sole, Age-1 Pacific halibut, or adult starry flounder Platichthys stellatus

tribution of Age-0 rock sole between sides of the arena was similar, regardless of large fish identity $(G=1.51$, $\mathrm{df}=2, \mathrm{p}=0.471$ ). Subsequent testing against a 50:50 ratio of distribution indicated a significant preference by Age- 0 rock sole to be on the side of the arena opposite the larger fish $(G=23.24, \mathrm{df}=1, \mathrm{p}<0.001)$.

\section{Laboratory predation vulnerability experiments}

In predation experiments, halibut predators (Age-2) typically began searching for prey within several minutes of the lights being turned on. Search was saltatory, with predators alternating between forward movements of 10 to $100 \mathrm{~cm}$, interspersed with pauses lasting from several seconds to several minutes, combined with frequent directional changes. Search occurred in close proximity to the bottom, with halibut predators rarely moving more than 10 to $20 \mathrm{~cm}$ off the substrate. When encountering the arena wall, predators would frequently pause briefly, then swim along the wall for a short distance, typically 30 to $100 \mathrm{~cm}$, before moving away from the wall and continuing their search in the interior of the arena. The presence or absence of shell had little influence on the vulnerability of Age-0 flatfish to predation (Fig. 6) because the mean number of Age-0 flatfish consumed over the course of the $4 \mathrm{~h}$ experiment did not differ between habitat treatments $\left(F_{[1,20]}=0.23, \mathrm{p}=0.635\right)$. There was a significant difference between Age-0 rock sole and halibut in their vulnerability to predation: Age-0 halibut were consumed in greater numbers than were Age-0 rock sole $\left(F_{[1,20]}=11.36, \mathrm{p}=0.003\right)$. This difference was consistent in trials both with and without shell $\left(F_{[1,20]}=0.14, \mathrm{p}=0.712\right)$. 


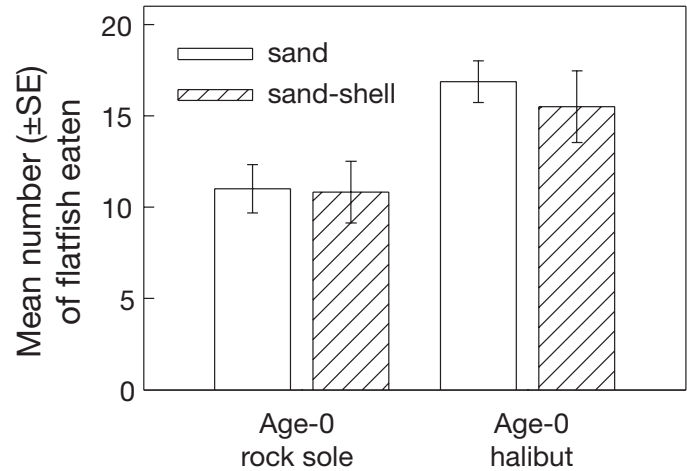

Fig. 6. Predation vulnerability. Mean number $( \pm \mathrm{SE})$ of either Age-0 rock sole Lepidopsetta polyxystra or Pacific halibut Hippoglossus stenolepis consumed by Age-2 Pacific halibut predators over $4 \mathrm{~h}$ in $3 \mathrm{~m}$ arenas with either sand or sand-shell substrate. Trials were initiated with 20 prey (either rock sole or halibut) and 2 predators

\section{DISCUSSION}

Because of their intimate association with the sediment, flatfish are not typically viewed as structure dependent (Able et al. 2005), yet emergent structure may contribute to habitat quality for some species (e.g. winter flounder, Stoner et al. 2001). Field studies demonstrate that Age-0 rock sole associate with emergent structure in inshore nurseries during their first summer (Stoner \& Titgen 2003, Stoner et al. 2007). Lack of preference by Age-0 rock sole for habitat, including scattered shell in our laboratory experiment, likely reflects a loose association with such structure at this ontogenetic stage, which is not readily demonstrable in the confined laboratory apparatus we utilized. Similarly, despite a strong association with vegetated habitats in the field (Zostera marinaand Laminaria saccharina-dominated habitat), Age-0 Pacific cod Gadus macrocephalus fail to demonstrate a clear association with $Z$. marina in laboratory trials unless tested in larger (10 m long) tanks in which their association becomes more readily detectable (Laurel et al. in press). Yet, by 1 yr of age, rock sole displayed a strong attraction for shell debris, both in the field and in our laboratory experiments. Similarly, Walton (1982) found that placement of artificial tire-reefs increased the abundance of adult rock sole on the surrounding seafloor in Puget Sound. Thus, preference for structured habitat appears to increase with age in juvenile rock sole, an ontogenetic shift that likely factored into the results of our field manipulations, as discussed below.

Predicting habitat quality for juvenile flatfish on the basis of emergent structural complexity alone, or in conjunction with traditional variables (e.g. temperature, depth, and sediment), ignores important biologi- cal aspects of habitat quality. In this study, the presence of larger flatfish, mostly Lepidopsetta spp., appears to have had a direct influence on habitat quality as perceived by Age-0 flatfish and, predominantly, rock sole. At Holiday Beach, where large flatfish were infrequently encountered, the few that were present in the shell treatments appeared to have had little influence on juvenile flatfish distribution, and small flatfish were aggregated on the shell-enhanced bottom. In contrast, at Pillar Creek Cove, where large flatfish were nearly an order of magnitude more abundant, their aggregation in shell treatment caused Age-0 flatfish to emigrate. We hypothesize that Age-0 rock sole were responding to larger conspecifics as predators, and that their elevated abundance in the shell treatments negated any attraction Age- 0 rock sole would have otherwise displayed for this habitat. In our laboratory experiments, Age-0 rock sole moved so as to avoid proximity to larger flatfish. Similarly, in other laboratory experiments, we observed that Age-0 rock sole, halibut and English sole all respond to a variety of larger fishes, as well as human disturbance, with stereotypic anti-predator behaviors (Ryer et a. 2004, Lemke \& Ryer 2006a,b, C. H. Ryer \& T. P. Hurst unpubl.). For example, all 3 initially responded to a model summer flounder Paralichthys dentatus-a species with which they have no geographic overlap - with lowered body posture, increased burial and a cessation of activity (K. Boersma \& C. Ryer unpubl. data), behavior that maximizes the effectiveness of their cryptic coloration and body morphology. While rock sole $>1 \mathrm{yr}$ are not typically considered piscivorous (Oñate 1991), it is plausible that they (especially the adults) would be regarded as threatening by juveniles, particularly given the risk-averse nature of Age-0 rock sole (Lemke \& Ryer 2006a), and because these larger fish were aggregated in a habitat that does little to mitigate predator-prey interactions, either by impeding predator penetration of the habitat (Bartholomew et al. 2000) or by facilitating prey escape tactics (Ryer et al. 2004).

Relocation to habitats with lower perceived risk has been widely observed. Bluegill sunfish Lepomis macrochirus respond to elevated open water predation risk by shifting to littoral vegetation, where risk is lower but so is foraging return - the classic trade-off (Werner \& Hall 1988). Similarly, spiny lobster Pannulirus argus emigrate in response to elevated risk of predation by triggerfish Balistes capriscus as well as to human disturbance (Parsons \& Eggleston 2006). In this study, Age-0 flatfish moved to areas where there were fewer large flatfish in less than $48 \mathrm{~h}$. However, over longer time scales, particularly when relocation is not an option, chronic exposure to elevated perceived risk may result in behavioral modifications that suppress growth (Nelson et al. 2004), inducible morphological defenses 
(Pettersson \& Brönmark 1997), and life-history alterations (Billerbeck et al. 2001, Munch \& Conover 2003, Hutchings 2005). The anti-predator tactics employed by rock sole and halibut (Lemke \& Ryer 2006a) preclude foraging, and recent laboratory study demonstrated reduced growth in Age-0 rock sole exposed to chronic predation risk (C. H. Ryer \& T. P. Hurst unpubl.). To mitigate chronic risk, fish may alter how and when they feed in a given habitat so as to minimize the ratio of predation risk to foraging reward (Fraser \& Metcalfe 1997, Metcalfe et al. 1998, Metcalfe \& Steele 2001). Rock sole exhibit crepuscular activity peaks (Hurst \& Duffy 2005), concentrating their feeding activity at dusk (Hurst et al. 2007). Such a temporal shift in feeding activity to mitigate predation risk would be consistent with their risk-averse behavioral strategy.

Another non-mutually exclusive hypothesis that may account for the results of our field experiments is that Age-0 rock sole respond to larger conspecifics as competitors. Supporting the competitive argument, flatfish are known to exhibit density dependent habitat preference. In laboratory experiments (Laurel et al. 2007), juvenile rock sole and halibut were given access to 2 bottom types: sand, which is preferred, and gravel. Fish began to reduce their occupancy of the preferred habitat when density there exceeded 1 to 2 fish $\mathrm{m}^{-2}$, though this tipping point varied somewhat among species, age classes and with temperature. However, no behavior that would indicate the mechanistic nature of this density dependence was observed. Since rock sole of all yearclasses consume predominantly infaunal and epibenthic invertebrate prey (Oñate 1991, Hurst et al. 2007), competition is presumably trophic; however, given the generic increase in trophic niche breadth that accompanies greater size, i.e. mouth gape (Scharf et al. 2000), this competition is unlikely to be excessive. However, if larger fish exhibit a higher threshold for the onset of density dependent interactions, which would likely occur in a strongly preferred habitat (i.e. shell), then tolerance for crowding would be asymmetric, potentially leading to the emigration of smaller fish from the shell habitat.

These behaviorally mediated effects, be they a result of risk aversion, competition, or both, suggest that overlap with other species and ages of fish will likely be important in determining how juvenile fish view habitat quality. Since community composition varies geographically, it follows that the quality of particular types of bottom may also vary in quality from one locale to another. Hurst \& Abookire (2006) documented lower growth rates for Age-0 rock sole at Pillar Creek Cove than at the Holiday Beach site. They speculated that differences in forage base were likely responsible. These nursery areas are similar with respect to depth, sediment characteristics, biogenic activity, and the distribution of emergent habitat structure that influences the distribution of Age-0 flatfish. Indeed, generalized additive models (GAMs) suggest that the same features control the distribution of Age-0 flatfish in both nurseries (Stoner et al. 2007). However, both this study and additional field data (Alaska Fisheries Science Center, AFSC unpubl. data) indicate that larger flatfish are more abundant at Pillar Creek Cove than at Holiday Beach, perhaps because of the former's closer proximity to deep water. This raises the possibility that indirect predator and/or competitive effects leading to growth suppression (C. H. Ryer \& T. P. Hurst unpubl.) may be responsible for growth-rate discrepancies between Pillar Creek Cove and Holiday Beach. While speculative at this juncture, this topic merits further research because it addresses a potentially critical short-coming prevalent in most EFH research: that is, evaluation of direct and indirect influences of predation (or competition) and the role they play in determining habitat quality for juvenile fishes.

In conclusion, characterization of EFH or 'habitat quality' for many flatfish species is more complicated than simply modeling fish abundance relative to sediment grain size, depth and temperature. Many species are associated with physical structures on the seafloor such as vegetation, organic debris, sand waves and biogenic structures. This realization has led to increased interest in understanding the capacity of various bottom habitats characterized by these features to support productive fish populations. This need is all the more compelling because these habitats are often susceptible to disturbances associated with trawl fisheries (Freese et al. 1999, Collie et al. 2005). In this study, Age-0 rock sole distribution was modified by aggregations of larger flatfish, demonstrating that community composition, which varies with depth and geography, can alter habitat preferences and, as such, should be considered as a factor in defining habitat quality.

Acknowledgements. We thank E. Munk for logistical support and assistance with field manipulations and collection of fish. M. Ottmar. P. Iseri and S. Haines assisted with field work, fish husbandry and laboratory experiments. T. Tripp captained F/V 'Miss-O' and his expert navigational skills made the camera sled work possible. We thank C. Sweitzer for assistance in manuscript preparation. Oregon Coast Aquarium loaned starry flounders for the laboratory experiments. T. Hurst, B. Laurel and 3 anonymous reviewers provided useful comments on an early draft of this manuscript. This research was funded in part by the North Pacific Research Board (Grant No. R0301 to C.R., A.S. and A.A.).

\section{LITERATURE CITED}

Able KW, Neuman MJ, Wennhage H (2005) Ecology of juvenile and adult stages of flatfishes: distribution and dynamics of habitat associations. In: Gibson RN (ed) Flatfishes. Blackwell Science, Oxford, p 164-184 
Abookire AA, Norcross BL (1998) Depth and substrate as determinants of distribution of juvenile flathead sole (Hippoglossoides elassodon) and rock sole (Pleuronectes bilineatus), in Kachemak Bay, Alaska. J Sea Res 39:113-123

Abookire AA, Duffy-Anderson JT, Jump CM (2007) Habitat associations and diet of young-of-the-year Pacific cod (Gadus macrocephalus) near Kodiak, Alaska. Mar Biol 150: 713-726

Amezcua F, Nash RDM (2001) Distribution of the order Pleuronectiformes in relation to the sediment type in the North Irish Sea. J Sea Res 45:293-301

Auster PJ, Malatesta RJ, Langton RW, Watling L and 5 others 1996) The impacts of mobile fishing gear on seafloor habitats in the Gulf of Maine (northwest Atlantic): implications for conservation of fish populations. Rev Fish Sci 4:185-202

Bartholomew A, Diaz RJ, Cicchetti G (2000) New dimensionless indices of structural habitat complexity: predicted and actual effects on a predator's foraging success. Mar Ecol Prog Ser 206:45-58

Billerbeck JM, Lankford Jr TE, Conover DO (2001) Evolution of intrinsic growth and energy acquisition rates. I. Tradeoffs with swimming performance in Menidia menidia. Evolution 35:1863-1872

Collie JS, Hermsen JM, Valentine PC, Almeida FP (2005) Effects of fishing on gravel habitats: assessment and recovery of benthic megafauna on Georges Bank. In: Barnes PW, Thomas JP (eds) Benthic habitats and the effects of fishing. American Fisheries Society, Bethesda, MD, p 325-343

Fraser NHC, Metcalfe NB (1997) The costs of becoming nocturnal: feeding efficiency in relation to light intensity in juvenile Atlantic salmon. Funct Ecol 11:385-391

Freese L, Auster PJ, Heifetz J, Wing BL (1999) Effects of trawling on seafloor habitat and associated invertebrate taxa in the Gulf of Alaska. Mar Ecol Prog Ser 182:119-126

Gibson RN (1994) Impact of habitat quality and quantity on the recruitment of juvenile flatfishes. Neth J Sea Res 32: 191-206

Gibson RN, Robb L (1992) The relationship between body size, sediment grain size and the burying ability of juvenile plaice, Pleuronectes platessa L. J Fish Biol 40:771-778

Gibson RN, Robb L, Wennhage H, Burrows MT (2002) Ontogenetic changes in depth distribution of juvenile flatfishes in relation to predation risk and temperature on a shallowwater nursery ground. Mar Ecol Prog Ser 229:233-244

Goldberg R, Phelan B, Pereira J, Hagan S and 5 others (2002) Variability in habitat use by young-of-the-year winter flounder, Pseudopleuronectes americanus, in three northeastern US estuaries. Estuaries 25:215-226

Hicks C (1982) Fundamental concepts in the design of experiments. Holt Rinehart \& Winston, New York

Hovel KA, Lipcius RN (2001) Habitat fragmentation in a seagrass landscape: patch size and complexity control blue crab survival. Ecology 82:1814-1829

Howell PT, Molnar DR, Harris RB (1999) Juvenile winter flounder distribution by habitat type. Estuaries 22:1090-1095

Hurst TP, Abookire AA (2006) Temporal and spatial variation in potential and realized growth rates of Age-0 year rock sole. J Fish Biol 68:905-919

Hurst TP, Duffy TA (2005) Activity patterns in northern rock sole are mediated by temperature and feeding history. J Exp Mar Biol Ecol 325:201-213

Hurst TP, Ryer CH, Ramsey JA, Haines SA (2007) Divergent foraging strategies of three co-occurring north Pacific flatfishes. Mar Biol 151:1087-1098

Hutchings JA (2005) Life history consequences of overexploitation to population recovery in Northwest Atlantic cod (Gadus morhua). Can J Fish Aquat Sci 62:824-832
Jager Z, Kleef L, Tydeman P (1993) The distribution of 0-group flatfish in relation to abiotic factors on the tidal flats in the brackish Dollard (Ems estuary, Wadden Sea). J Fish Biol 43: 31-43

Killen SS, Brown JA (2006) Energetic cost of reduced foraging under predation threat in newly hatched coean pout. Mar Ecol Prog Ser 321:255-266

Krygier EE, Pearcy WG (1986) The role of estuarine and offshore nursery areas for young English sole, Parophrys vetulus Girard, of Oregon. Fish Bull 84:119-132

Laurel BJ, Gregory RS, Brown JA (2003) Predator distribution and habitat patch area determine predation rates on Age-0 juvenile cod Gadus spp. Mar Ecol Prog Ser 251:245-254

Laurel BJ, Stoner AW, Hurst TP (2007) Density-dependent habitat use in marine flatfish: the dynamic role of ontogeny and temperature. Mar Ecol Prog Ser 338: 183-192

Laurel BJ, Stoner AW, Ryer CH, Hurst TP, Abookire AA (in press) Comparative habitat associations in juvenile Pacific cod and other gadids using seines, baited cameras and laboratory techniques. J Exp Mar Biol Ecol

Lemke JL, Ryer CH (2006a) Risk sensitivity in three juvenile (Age-0) flatfish species: Does estuarine dependence promote risk-prone behavior? J Exp Mar Biol Ecol 333:172-180

Lemke JL, Ryer CH (2006b) Relative predation vulnerability of three juvenile (Age-0) North Pacific flatfish species: possible influence of nursery specific predation pressures. Mar Ecol Prog Ser 328:267-273

Manderson JP, Phelan BA, Stoner AW, Hilbert J (2000) Predator-prey relations between age-1+ summer flounder (Paralichthys dentatus, Linnaeus) and age-0 winter flounder (Pseudopleuronectes americanus, Walbaum): predator diets, prey selection, and effects of sediments and macrophytes. J Exp Mar Biol Ecol 251:17-39

McConnaughey RA, Smith KR (2000) Associations between flatfish abundance and surficial sediments in the eastern Bering Sea. Can J Fish Aquat Sci 57:2410-2419

Metcalfe NB, Steele GI (2001) Changing nutritional status causes a shift in the balance of nocturnal to diurnal activity in European Minnows. Funct Ecol 15:304-309

Metcalfe NB, Fraser NHC, Burns MD (1998) State-dependent shifts between nocturnal and diurnal activity in salmon. Proc R Soc Lond B 265:1503-1507

Munch SB, Conover DO (2003) Rapid growth results in increased susceptibility to predation in Menidia menidia. Evolution 57:2119-2127

Nelson EH, Matthews CE, Rosenheim JA (2004) Predators reduce prey populations growth by inducing changes in prey behavior. Ecology 85:1853-1858

Norcross BL, Blanchard A, Holladay BA (1999) Comparison of models for defining nearshore flatfish nursery areas in Alaskan waters. Fish Oceanogr 8:50-67

Oñate FC (1991) Food and daily ration of the rock sole Lepidopsetta bilineata (Pleuronectidae) in the eastern Bering Sea. Mar Biol 108:185-191

Parsons DM, Eggleston DB (2006) Human and natural predators combine to alter behavior and reduce survival of Caribbean spiny lobster. J Exp Mar Biol Ecol 334:196-205

Pettersson LB, Brönmark C (1997) Density-dependent costs of an inducible morphological defense in crucian carp. Ecology 78:1805-1815

Rogers SI (1992) Environmental factors affecting the distribution of sole (Solea solea L.) within a nursery area. Neth J Sea Res 29:153-161

Ryer CH, Stoner AW, Titgen RH (2004) Behavioral mechanisms underlying the refuge value of benthic habitat structure for two flatfishes with differing anti-predator strategies. Mar Ecol Prog Ser 268:231-243 
Scharf FS, Juanes F, Roundtree RA (2000) Predator size-prey size relationships of marine fish predators: interspecific variation and effects of ontogeny ad body size on trophicniche breadth. Mar Ecol Prog Ser 208:229-248

Schmitten RA (1999) Essential fish habitat: opportunities and challenges for the next millennium. In: Benaka L (ed) Fish habitat: essential fish habitat and rehabilitation. American Fisheries Society, Bethesda, MD, p 3-10

Sokal RR, Rohlf FJ (1969) Biometry. WH Freeman, San Francisco

Spencer ML, Stoner AW, Ryer CH, Munk JE (2005) A towed camera sled for estimating abundance of juvenile flatfishes and habitat characteristics: comparison with beam trawls and divers. Estuar Coast Shelf Sci 64: 497-503

Stoner AW, Abookire AA (2002) Sediment preferences and size-specific distribution of young-of-the-year Pacific halibut in an Alaska nursery. J Fish Biol 61:540-559

Stoner AW, Ottmar ML (2003) Relationships between size-specific sediment preferences and burial capabilities in juveniles of two Alaska flatfishes. J Exp Mar Biol Ecol 282: 85-101

Editorial responsibility: Kenneth Heck (Contributing Editor), Dauphin Island, Alabama, USA
Stoner AW, Titgen RH (2003) Biological structures and bottom type influence habitat choices made by Alaska flatfishes. J Exp Mar Biol Ecol 292:43-59

Stoner AW, Manderson JP, Pessutti JP (2001) Spatially explicit analysis of estuarine habitat for juvenile winter flounder: combining generalized additive models and geographic information systems. Mar Ecol Prog Ser 213:253-271

Stoner AW, Spencer ML, Ryer CH (2007) Flatfish-habitat associations in Alaska nursery grounds: use of continuous video records for multi-scale spatial analysis. J Sea Res 57: 137-150

Swartzman G, Huang C, Kaluzny S (1992) Spatial analysis of Bering Sea groundfish survey data using generalized additive models. Can J Fish Aquat Sci 49:1366-1378

Thrush SF, Schultz D, Hewitt JE, Talley D (2002) Habitat structure in soft-sediment environments and abundance of juvenile snapper Pagrus auratus. Mar Ecol Prog Ser 245: 273-280

Walton JM (1982) The effects of an artificial reef on resident flatfish populations. Mar Fish Rev 44:45-48

Werner EE, Hall DJ (1988) Ontogenetic habitat shifts in bluegill: the foraging rate-predation risk trade-off. Ecology 69:1352-1366

Submitted: August 1, 2006; Accepted: February 14, 2007

Proofs received from author(s): July 13, 2007 